\title{
DEVELOPMENT OF STRENGTH IN THE CLASSES OF PHYSICAL EDUCATION FROM STUDENTS IN PRISON
}

\author{
L.G. Talaghir, gtalaghir@ugal.ro, ORCID: 0000-0002-3133-9192, \\ G.D. Mocanu, gmocanu@ugal.ro, ORCID: 0000-0002-4763-4700, \\ T.M. Iconomescu, ticonomescu@ugal.ro, ORCID: 0000-0001-5780-4403 \\ "Dunarea de Jos" University of Galati, Galati, Romania
}

\begin{abstract}
Aim. Muscle strength development is a priority of physical education and sports activities for all training cycles, due to the importance that the motor skills, strength - with its forms of manifestation and combinations with other skills - has in the manifestation of students' motor potential. The aim of our research was to study strength - with its forms of manifestation and combinations with other skills in special education in prison regime, which imposes distinct measures of approaching to educational process. Materials and methods. The study took place at Tichilesti Special Secondary School (Braila County) with prison regime for minors and youth, during the school year 2016-2017, for both semesters. The study was divided into two distinct stages, differentiated in two main learning units, i.e. in the first semester - 18 lessons and in the second semester -8 lessons. Results. The statistical processing of the results - obtained by the students from the experimental group - highlights a strong and significant progress for all used tests, which confirms the statistic hypothesis and strengthens the privileged position that the work in circuit method holds in school physical education, in order to optimize the muscle strength. Conclusion. The results obtained through the implementation of the experimental curriculum confirm its importance and viability but the fact that the control group achieves significant and similar performance leaps to the experimental group, demonstrates that the other traditional methods of muscle strength education are useful and that they cannot be removed from the training process.
\end{abstract}

Keywords: adult students, education in prison, method of working in circuit, physical education.

Introduction. The age at which the development of strength starts is a controversial issue, which has preoccupied numerous specialists especially in the last years, but the observations and studies performed in this direction allow us to suppose that the exercises for the development of strength not only stop growth, but by the general intensification of metabolism, help the normal development of children and teenagers $[4,11,12$, $21]$. In the special literature there are numerous exercises and drive systems for developing strength, these being performed by complying with the rules of diversified methods, adapted according to the type of strength planned and the possibilities of students in different training cycles: isotonic method, isometric contraction method, eccentric contractions method, work in workshops/stations, method of working in the circuit, plyometric method, ballistic method, bodybuilding method, power-training method, weightlifter's method, using applicative itineraries etc. [2].

The information explosion in the past years especially on the internet, where there are many exercises for developing strength and programs for general or specific physical training - allows the teachers to adapt these proposed variants, according to the groups they work with, to verify their efficiency and practical applicability $[8,14$, 18]. The influence that the physical exercise exerts - including the one dominantly oriented to muscle strength - on the student, is decisive for shaping his personality, so that in the future it answers and corresponds to the finalities of each curriculum cycle of education and then to the social demands, according to specialized curricula $[15,17,21]$. Such an evolution can only be achieved by taking into account the individual particularities and the needs of the group, the material conditions offered by the school unit, the limits often imposed by these factors. The teenage stage (14/15 - 18/20 years) which follows the puberty crisis - is characterized by hormonal changes, development of the reproductive function, manifestation of self-consciousness, shaping of personality and interests [7].

The adolescence is characterized by quantitative and qualitative accumulations on the so- 


\section{Спортивная тренировка}

matic and functional level, which generates special leaps in motor skills, too. The motor skills formed at previous stages are consolidated and even improved, being integrated in various types of educational, motor, leisure and competitive activities etc. $[3,5,6]$.

Muscle fibre hypertrophy occurs, the active muscle mass reaches average values of $44 \%$ of the body mass at boys and $37 \%$ at girls. Bones grow more in width than in length, growth in girls almost stagnates, while in boys may continue insignificantly at the trunk level. Body mass accumulations are 1-2 kg/year, with smaller and smaller values to the end of the period / 20 years, but the general development of the body segments tends more towards harmony $[2,10]$. The functional parameters record improvements which allow the body to cope with sustained efforts in volume and intensity. Maximum oxygen consumption, breathing amplitude, heart rate, systolic flow and cardiac output are approaching the values characteristic to adults, which contributes to the improvement of performance at all levels. The vital capacity increases in correlation with the body mass and body height, breathing rate reaches values of 20 breaths/minute [19].

Based on muscle hypertrophy, strength can be developed in all its forms of manifestation. The majority of literature sources indicate the fact that at the age of 14 girls have $50 \%$ of opportunities, while boys $60 \%$; at the age of 18 , boys' muscle strength increases up to $90 \%$, while in girls of the same age it reaches only $60 \%$. As for maximum strength, girls have values $40 \%$ lower than the absolute maximum strength of boys, the differences are determined by the quantity of androgenic hormones, whose evolution is similar to the development of muscle mass $[9,13,16]$.

\section{Materials and Methods}

Subjects. We studied students from five classes (experimental class - 15 subjects and control class -14 subjects). Due to the fact that the groups were made up of subjects who exceed the standard age corresponding to the secondary cycle, the curriculum was adapted to their chronological age, i.e. the age of the students in the last year of high school $( \pm 19.4$ years the experimental class; \pm 20.2 years the control class).

Procedure. The study took place at Tichilesti Special Secondary School, Braila County, a school unit with prison regime for minors and youth. The study was performed during school year 2016-2017, for both semesters.

The work interval allotted to both classes for developing muscle strength is divided in two distinct stages, differentiated in two main learning units, i.e. 18 lessons in the first semester and 8 lessons in the second semester. Several forms of muscle strength have been studied: segmental dynamic strength, explosive strength, strength in resistance regime, with the indication that the experimental class used only work in the circuit method, while the control class used the other methods presented in special literature. Table 1 demonstrates the distribution of hours for students' physical education during school year 2016/2017.

Table 1

\section{Learning units for motor skills and their allocation by semesters}

\begin{tabular}{|c|l|c|c|c|}
\hline \multirow{2}{*}{$\begin{array}{c}\text { Contents } \\
\text { of the curri- } \\
\text { culum }\end{array}$} & Contents & \multicolumn{2}{|c|}{$\begin{array}{c}\text { No. of allotted } \\
\text { lessons }\end{array}$} & \multirow{2}{*}{ Total } \\
\cline { 3 - 5 } & & Sem. I & Sem. II & \\
\hline \multirow{4}{*}{$\begin{array}{l}\text { Motor } \\
\text { qualities }\end{array}$} & Speed & - & 8 & 8 \\
\cline { 2 - 5 } & Coordination & 10 & - & 10 \\
\cline { 2 - 5 } & Strength & $\mathbf{1 8}$ & $\mathbf{8}$ & $\mathbf{2 6}$ \\
\cline { 2 - 5 } & Resistance & - & 10 & 10 \\
\cline { 2 - 5 } & Combined & - & 6 & 6 \\
\hline
\end{tabular}

Circuits with 6-8 stations were planned in the experiment, which are at the medium level in terms of duration $[1,20]$. We preferred a variant with 30 seconds break and 30 seconds rest between the stations, load at each station was distributed according to the rule/formula:

$$
\begin{aligned}
& \text { Individual load }=\frac{\text { no.of } \max \text { repetitions }}{2}+ \\
& + \text { growth rate, }
\end{aligned}
$$

with the observation that in designing and completing the circuits, the fundamental rules of alternation shown in Fig. 1 were complied with.

We demonstrate the example of 8-station circuit variant, which was used during the experiment:

- from the standing position, with two dumbbells held in hands, climb on the bench, descend and squat;

- with spread legs, in pairs, standing face to face, pass the medicine ball $(2-3 \mathrm{~kg})$ with one hand from the shoulder and catch it;

- from lying on the back, with arms in the extension of the body, holding a medicine ball in hands, raise the trunk vertically and return to the previous position;

- from lying on the stomach on the bench, with hands behind the head, trunk extensions and return to previous position; 


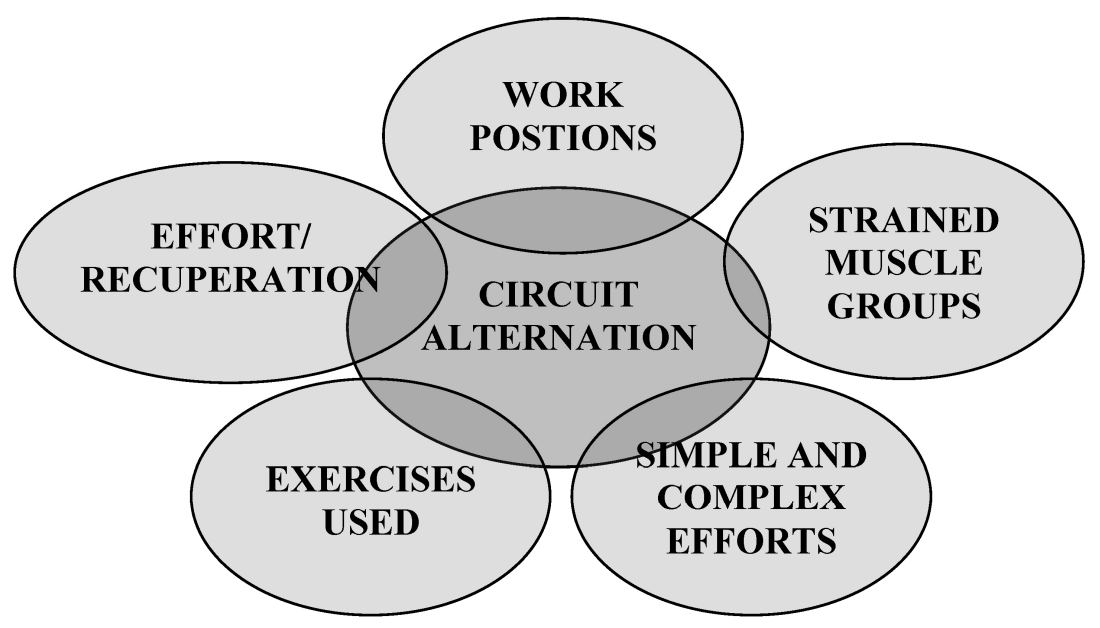

Fig. 1. Main rules of alternation in the design and implementation of circuits

- from a squatting position, vertical jumps and returning to squatting position;

- lying on the stomach, with the feet resting on the bench, palms on the ground, spread at shoulder width, push-ups are performed with chest near the ground;

- hanging from fixed ladder, raise knees to the chest or stretch legs forward/set-square position and return to previous position;
- spread legs, with dumbbell on shoulders and variable weight, flex the trunk on the pelvis and return to previous position;

Results and discussion. Research results are presented in tables, differentiated by classes. Students participated in 10 tests which target all large muscle groups and body regions - abdomen, back, upper limbs and lower limbs. Table 2 presents the results and statistical indicators

Statistical indicators obtained by boys in the experimental group $(n=15)$

Table 2

\begin{tabular}{|l|c|c|c|c|c|c|c|c|c|}
\hline \multirow{2}{*}{ Test } & \multicolumn{2}{|c|}{$\overline{\boldsymbol{x}}$} & \multicolumn{2}{c|}{$\mathbf{W}$} & \multicolumn{2}{c|}{$\pm \mathbf{S}$} & \multicolumn{2}{c|}{$\mathbf{C v} \%$} & \multirow{2}{*}{ t } \\
\cline { 2 - 11 } & $\mathrm{Ti}$ & $\mathrm{Tf}$ & $\mathrm{Ti}$ & $\mathrm{Tf}$ & $\mathrm{Ti}$ & $\mathrm{Tf}$ & $\mathrm{Ti}$ & $\mathrm{Tf}$ & \\
\hline Hanging (sec.) & 63,0 & 66,3 & 22,0 & 22,1 & $\pm 5,9$ & $\pm 5,8$ & $9,44 \%$ & $8,74 \%$ & $4,05^{*}$ \\
\hline Pull-ups (no. of executions) & 15,0 & 18,2 & 7,0 & 8,0 & $\pm 2,1$ & $\pm 2,1$ & $14,51 \%$ & $11,78 \%$ & $12,22^{*}$ \\
\hline Push-ups (no. of executions) & 17,2 & 20,5 & 7,00 & 6,0 & $\pm 2,1$ & $\pm 2,1$ & $12,27 \%$ & $10,71 \%$ & $15,83^{*}$ \\
\hline $\begin{array}{l}\text { Simultaneous lifting } \\
\text { of the trunk and legs while } \\
\text { lying on the back } \\
\text { (no. of executions) }\end{array}$ & 11,6 & 15,3 & 5,0 & 6,0 & $\pm 1,5$ & $\pm 1,5$ & $12,95 \%$ & $10,36 \%$ & $15,04^{*}$ \\
\hline $\begin{array}{l}\text { Lowering and lifting } \\
\text { of the trunk while sitting } \\
\text { on the bench } \\
\text { (no. of executions) }\end{array}$ & 14,4 & 17,8 & 6,0 & 7,0 & $\pm 1,9$ & $\pm 2,0$ & $13,54 \%$ & $11,27 \%$ & $11,60^{*}$ \\
\hline $\begin{array}{l}\text { Lateral lunges } \\
\text { (no. of executions) }\end{array}$ & 14,6 & 25,0 & 6,0 & 10,0 & $\pm 1,8$ & $\pm 3,2$ & $12,79 \%$ & $12,83 \%$ & $12,75^{*}$ \\
\hline Standing long jump (cm) & 204,1 & 217,2 & 40,0 & 30,0 & $\pm 12,9$ & $\pm 9,5$ & $6,36 \%$ & $4,41 \%$ & $8,38^{*}$ \\
\hline $\begin{array}{l}\text { Three successive standing } \\
\text { long jumps (m) }\end{array}$ & 5,7 & 5,9 & 0,6 & 0,5 & $\pm 0,1$ & $\pm 0,1$ & $3,31 \%$ & $2,67 \%$ & $12,04 *$ \\
\hline $\begin{array}{l}\text { Lifting the trunk } \\
\text { from the position lying } \\
\text { on the stomach } \\
\text { (no. of executions) }\end{array}$ & 24,6 & 28,7 & 8,0 & 5,0 & $\pm 2,5$ & $\pm 1,2$ & $10,46 \%$ & $4,45 \%$ & $10,95^{*}$ \\
\hline $\begin{array}{l}\text { Back extension while lying } \\
\text { on the stomach on the bench } \\
\text { (no. of executions) }\end{array}$ & 17,3 & 21,5 & 6,0 & 5,0 & $\pm 1,7$ & $\pm 1,6$ & $10,14 \%$ & $7,82 \%$ & $21,00^{*}$ \\
\hline
\end{tabular}

Note: $* \mathbf{P}<\mathbf{0 , 0 0 1}$. 


\section{Спортивная тренировка}

obtained in initial and final tests by the experimental group.

The statistical processing of the results obtained by the students from the experimental group highlights a strong and significant progress for all tests, which confirms our hypothesis and strengthens the privileged position that the work in circuit method holds in school physical education in order to optimise the muscle strength. All $\mathrm{t}$ values correspond to some significant thresholds $\mathrm{P}<0,001$, which means that all the differences between the final and initial tests are significant and cannot be due to other external influences. This proves that the curriculum proposed is viable.

The groups studied demonstrated results which indicate a high homogeneity for three of the tests used $-1,7$, and $8-$ meaning that the value of $\mathrm{Cv}$ is less than $10 \%$, in both initial and final testing. For the rest of the tests, $\mathrm{Cv}$ values are between 10-20\%, which indicates an average homogeneity of the assessed group. No Cv values over $20 \%$ are recorded at any test, indicating a lack of homogeneity.
The results and statistical calculation of the results obtained by boys from the control/witness group are presented in Table 3. As we can see, in this case, too, in all tests used for this group, the differences between the initial and final average values are strongly significant, the values of $t$ are afferent to some significance thresholds $\mathrm{P}<0.001$, which leads to the idea that the other methods of strength development for the control group also are of high efficiency, allowing the obtaining of the performance similar to the experimental group. The variability coefficients calculated for initial and final testing are consistent with values that indicate a high and average homogeneity, situation encountered in boys in the experimental group, too.

Conclusions. The results obtained through the implementation of the experimental curriculum confirm its importance and viability. However, the fact that the control group achieves significant performance similar to the experimental group, demonstrates that other traditional methods of muscle strength education are also useful and cannot be removed from the training process.

Statistical indicators obtained by boys in the control group $(n=14)$

Table 3

\begin{tabular}{|c|c|c|c|c|c|c|c|c|c|}
\hline \multirow{2}{*}{ Test } & \multicolumn{2}{|c|}{$\bar{x}$} & \multicolumn{2}{|c|}{$\mathbf{W}$} & \multicolumn{2}{|c|}{$\pm \mathbf{S}$} & \multicolumn{2}{|c|}{$\mathrm{Cv}, \%$} & \multirow{2}{*}{$\mathbf{t}$} \\
\hline & $\mathrm{Ti}$ & $\mathrm{Tf}$ & $\mathrm{Ti}$ & $\mathrm{Tf}$ & $\mathrm{Ti}$ & Tf & $\mathrm{Ti}$ & $\mathrm{Tf}$ & \\
\hline Hanging (sec.) & 58,4 & 61,4 & 26,3 & 23,0 & $\pm 8,20$ & \pm 6.61 & $13,98 \%$ & $10,71 \%$ & $3,84 *$ \\
\hline $\begin{array}{l}\text { Pull-ups } \\
\text { (no. of executions) }\end{array}$ & 14,3 & 16,0 & 6,0 & 4,0 & $\pm 1,82$ & $\pm 1,54$ & $12,69 \%$ & $9,59 \%$ & $8,83 *$ \\
\hline $\begin{array}{l}\text { Push-ups } \\
\text { (no. of executions) }\end{array}$ & 16,7 & 18,4 & 7,0 & 7,0 & $\pm 2,32$ & $\pm 2,06$ & $13,85 \%$ & $11,20 \%$ & $7,30 *$ \\
\hline $\begin{array}{l}\text { Simultaneous lifting } \\
\text { of the trunk and legs } \\
\text { while lying on the back } \\
\text { (no. of executions) }\end{array}$ & 12,2 & 14,07 & 6,0 & 5,0 & $\pm 1,89$ & $\pm 1,43$ & $15,45 \%$ & $10,22 \%$ & $8,33 *$ \\
\hline $\begin{array}{l}\text { Lowering and lifting } \\
\text { of the trunk while sitting } \\
\text { on the bench } \\
\text { (no. of executions) }\end{array}$ & 14,0 & 15,6 & 6,0 & 6,0 & $\pm 2,07$ & $\pm 1,78$ & $14,82 \%$ & $11,38 \%$ & $12,36^{*}$ \\
\hline $\begin{array}{l}\text { Lateral lunges } \\
\text { (no. of executions) }\end{array}$ & 15,0 & 19,2 & 6,0 & 6,0 & $\pm 2,07$ & $\pm 1,93$ & $13,83 \%$ & $10,05 \%$ & $11,59 *$ \\
\hline Standing long jump (cm) & 202,2 & 210,2 & 50,0 & 43,0 & $\pm 14,99$ & $\pm 14,31$ & $7,41 \%$ & $6,80 \%$ & $7,96 *$ \\
\hline $\begin{array}{l}\text { Three successive standing } \\
\text { long jumps }(\mathrm{m})\end{array}$ & 5,8 & 5,9 & 0,4 & 0,4 & $\pm 0,14$ & $\pm 0,14$ & $2,42 \%$ & $2,42 \%$ & $10,50 *$ \\
\hline $\begin{array}{l}\text { Lifting the trunk } \\
\text { from the position lying } \\
\text { on the stomach } \\
\text { (no. of executions) }\end{array}$ & 25,4 & 27,1 & 7,0 & 7,0 & $\pm 2,10$ & $\pm 2,14$ & $8,26 \%$ & $7,89 \%$ & $6,44 *$ \\
\hline $\begin{array}{l}\text { Back extension while } \\
\text { lying on the stomach } \\
\text { on the bench } \\
\text { (no. of executions) }\end{array}$ & 16,4 & 18,2 & 7,0 & 8,0 & $\pm 2,24$ & $\pm 2,16$ & $13,65 \%$ & $11,83 \%$ & $7,32 *$ \\
\hline
\end{tabular}

Note: $* \mathbf{P}<\mathbf{0 . 0 0 1}$. 
The advantages of the circuit in the development of muscle strength are undeniable: accessibility, possibility of calculating individual effort, optimal use of sports materials, high motor and physiological density, various attractive exercises, etc. However, the method of working in circuit solves - usually at higher level - the development of the strength-resistance combination and allows for a sequential analytical processing of all segments and muscle groups. The beneficial effects of the explosive dynamic strength, of the submaximal and maximal strength, of the muscle hypertrophy are achieved by specific methodology, classified and described in a special literature and verified by the practice: the method of bodybuilding for hypertrophy, methods of power-training, plyometric, ballistic and counter-resistance for braking and explosive strength of the arms, the method of eccentric contractions, isometric method and the method of the weight lifter for accumulations with regard to maximum strength.

For these reasons, it is advisable to select and adapt working methods according to the type of strength, for example, for the development of the strength-coordination combination, we can plan exercises to overcome loads and have a more complex structure, logically ordered in applicative paths, in order to increase the level of effective involvement in the activity.

In the control group, exercises were used to develop segmental strength, dynamic strength, and strength in resistance regime by frontal work, framed in other methods. In both groups, the drive systems referred to above must comply with the recommended methodological guidelines for age, load, and number of repetitions, breaks, body recovery after the effort, especially stretching the strained muscles.

In order to be able to act with good results in the direction of strength development, it is necessary to have a good knowledge of the working team, both in terms of health and physical abilities, through initial and intermediate testing, monitoring the process how students adapt and respond to the effort. Following the observations based on students' behavioural analysis, we established a decrease of aggressive behavioural attitudes and a better responsiveness on assigned tasks.

The higher scores recorded by both groups for the whole test battery - can also be explained by the major gap between the chronological age the average is in the post-secondary period - and the study cycle where these pupils are enrolled according to the intellectual availability and competences formed to date, i.e. entrance in middle school. From the point of view of body maturing and the real possibilities of physical training, for these special classes there are no contraindications regarding the training methods, as the methodological limitations specific to the stage of puberty. Body growth from a somatic and functional point of view, as well as the concerns related to physical activity - specific to respective chronological age - are arguments which justify the performance of both groups studied.

\section{References}

1. Al-Haliq, M. [Using the Circuit Training Method to Promote the Physical Fitness Components of the Hashemite University Students]. Advances in Physical Education, 2015, iss. 5, pp. 170-175.

2. Amtmann J., Kukay J. [Fitness Changes after an 8-Week Fitness Coaching Program at a Regional Youth Detention Facility]. Journal of Correctional Health Care, 2015, iss. 22, no. 1, pp. $75-83$.

3. Battaglia C., Di Cagno A., Fiorilli G., Giombini A., Fagnani F., Borrione P., Pigozzi F. [Benefits of Selected Physical Exercise Programs in Detention: A Randomized Controlled Study]. International Journal of Environmental Research and Public Health, 2013, iss. 10, no. 11, pp. 5683-5696.

4. Cormac B., [Learning to Escape: Prison Education, Rehabilitation and the Potential for Transformation]. Journal of Prison Education and Reentry, 2014, iss. 1, no. 1, pp. 20-31.

5. Dragnea A., Bota A. Theory of motric activities, Bucuresti, EDPPubl., 1999, p. 140.

6. Gallant D., Sherry E., Nicholson M. [Recreation or rehabilitation? Managing sport for development programs with prison populations]. Sport Management Review, 2015, iss. 18, no. 1, pp. 45-56.

7. Golu F. Psychology of human development, BucureştiUniversitară Publ., 2010, p. 209.

8. Lewis G., Meek R. [Sport and physical education across the secure estate: an exploration of policy and practice]. Centre for Crime and Justice Studies, 2012, iss. 90, pp. 32-34.

9. Lubans D.R., Lonsdale C., Cohen K., Eather N., Beauchamp M.R., Morgan P.J., Sylvester B.D., Smith J.J. [Framework for the design and delivery of organized physical activity sessions for children and adolescents: rationale and 


\title{
Спортивная тренировка
}

description of the 'SAAFE' teaching principles]. International Journal of Behavioral Nutrition and Physical Activity, 2017, iss. 14, no. 24, pp. 1-11.

10. Mannocci A., Masala D., Mipatrini D., Rizzo J., Meggiolaro S., Di Thiene, D., La Torre G. [The relationship between physical activity and quality of life in prisoners: a pilot study]. Journal of Preventive Medicine and Hygiene, 2015, iss. 56, no. 4, pp. 172-175.

11. Meek R., Lewis G.E. [Promoting WellBeing and Desistance through Sport and Physical Activity: The Opportunities and Barriers Experienced by Women in English Prisons]. Women \& Criminal Justice, 2014, iss. 24, no. 2, pp. 151-172.

12. Meek R., Sport in Prison: Exploring the Role of Physical Activity in Correctional Settings, Routledge Publ., 2014, 214 p.

13. Mipatrini D., Mannocci A., Masala D., Di Thiene D., Rizzo J., Meggiolaro S., La Torre G. [The impact of physical activity on prisoners' Quality of Life in Italy: a multicenter study]. European Journal of Public Health, 2015, iss. 25, no. 3, p. 372.

14. Moscoso-Sánchez D., De Léséleuc E., Rodríguez-Morcillo L., González-Fernández M., Pérez-Flores A., Muñoz-Sánchez V. [Expected outcomes of sport practice for inmates: A comparison of perceptions of inmates and staff]. Revista de Psicología del Deporte, 2017, iss. 26, no. 1 , pp. 37-48.
15. Obadiora, A.H. [The influence of sport participation on quality of life perceptions among inmates in Nigerian prisons]. Journal of Sport for Development, 2016, iss. 4, no. 6, pp. 36-43.

16. Olaitan, S.A., Shmaila, H., Sikiru, L., \& Lawal, I.U. [Correlates of Selected Indices of Physical Fitness and Duration of Incarceration among Inmates in Some Selected Nigeria Prisons]. Ethiopian Journal of Health Sciences, 2010, iss. 20, no. 1, pp. 65-69.

17. Pantelis K. [The Attitudes of Prisoners regarding to Physical Activities and Sports]. Journal of Physical Education and Sport, 2014, iss. 14 , no. 4 , pp. 569-575.

18. Parker A., Meek R., Lewis G. [Sport in a youth prison: male young offenders' experiences of a sporting intervention]. Journal of Youth Studies, 2014, iss. 17, no. 3, pp. 381-396.

19. Stănescu M., Didactics of physical education. Craiova, Universitară Publ., 2012, p. 215.

20. Sujith S. Physical effects of different intensive circuit training on selected motor fitness physiological and biochemical statistics, First Edition, IJERSS Publ., 2016, p. 116.

21. Woods D., Hassan D., Breslin G. [Positive collateral damage or purposeful design: How sport-based interventions impact the psychological well-being of people in prison]. Mental Health and Physical Activity, 2017, iss. 13, pp. 152-162.

Received 19 November 2018

\section{РАЗВИТИЕ СИЛОВЫХ КАЧЕСТВ НА УРОКАХ ФИЗИЧЕСКОЙ КУЛЬТУРЫ У УЧЕНИКОВ, НАХОДЯЩИХСЯ В ТЮРЕМНОМ ЗАКЛЮЧЕНИИ}

\author{
Л.Г. Талагир, Дж.Д. Мокану, Т.М. Икономеску \\ Университет «Нижний Дунай», г. Галац, Румыния
}

Цель. Развитие мышечной силы является приоритетом физического воспитания и спорта на всех тренировочных циклах из-за необычайной важности двигательных и силовых навыков во всех формах своего проявления и сочетаниях с другими навыками. Целью нашего исследования является изучение навыка силы во всех формах его проявления и сочетаниях с другими навыками в контексте специализированного образования в тюремных условиях, накладывающего определенные ограничения на учебный процесс. Материалы и методы. Исследование проводилось в 2016-2017 гг. в специализированной школе с тюремным режимом Тичилешти, расположенной в жудеце Брэила. Общая продолжитель- 
ность исследования - два учебных семестра. В исследовании выделяются два этапа, соответствующие двум различным модулям: 18 занятий в первом семестре и 8 занятий во втором семестре. Результаты. Статистическая обработка результатов, полученных в экспериментальной группе, демонстрирует серьезный прогресс во всех проведенных тестированиях, что подтверждает статистическую гипотезу и подчеркивает правильность методов, используемых на уроках физической культуры для оптимизации мышечной силы. Заключение. Результаты, полученные после внедрения экспериментального расписания, доказывают его жизнеспособность. Тем не менее тот факт, что контрольная группа также достигает значительных успехов, говорит о действенности традиционных способов развития силы, которые не могут быть исключены из тренировочного процесса.

Ключевые слова: ученики старшего возраста, образование в тюрьме, круговые тренировки, физическое воспитание.

Талагир Лаурентиу-Габриэль, $\mathrm{PhD}$, профессор, факультет физического воспитания и спорта, кафедра индивидуальных видов спорта и кинетотерапии, Университет «Нижний Дунай». Ул. Домняскэ, 47. 800008, г. Галац, Румыния. E-mail: gtalaghir@ugal.ro, ORCID: 0000-0002-3133-9192.

Мокану Джордж Данут, $\mathrm{PhD}$, преподаватель, факультет физического воспитания и спорта, кафедра индивидуальных видов спорта и кинетотерапии, Университет «Нижний Дунай». Ул. Домняскэ, 47, 800008, г. Галац, Румыния. E-mail: gmocanu@ugal.ro, ORCID: 0000-0002-4763-4700.

Икономеску Теодора-Михаэла, $\mathrm{PhD}$, доцент, факультет физического воспитания и спорта, кафедра спортивных игр и физического воспитания, Университет «Нижний Дунай». Ул. Домняскэ, 47, г. Галац, 800008, Румыния, E-mail: ticonomescu@ugal.ro, ORCID: 0000-0001-5780-4403.

Поступила в редакцию 19 ноября 2018 г.

\section{ОБРАЗЕЦ ЦИТИРОВАНИЯ}

Talaghir, L.G. Development of Strength in the Classes of Physical Education from Students in Prison / L.G. Talaghir, G.D. Mocanu, T.M. Iconomescu // Человек. Спорт. Медицина. - 2018. - Т. 18, № S. - С. 83-89. DOI: 10.14529/hsm18s11

\section{FOR CITATION}

Talaghir L.G., Mocanu G.D., Iconomescu T.M. Development of Strength in the Classes of Physical Education from Students in Prison. Human. Sport. Medicine, 2018, vol. 18, no. S, pp. 83-89. DOI: 10.14529/hsm18s11 